\title{
Integrating 2,4-D and sheep grazing to rehabilitate spotted knapweed infestations
}

\author{
ROGER L. SHELEY, JAMES S. JACOBS, AND JOHN M. MARTIN
}

Authors are Rangeland Weed Ecologist, USDA-Agricultural Research Service and the Eastern Oregon Agricultural Research Center, Burns, Ore. 97720, Research Assistant Professor, Department of Land Resources and Environmental Sciences, and Professor, Plant Sciences, Montana State University, Bozeman, Mont. 59717.

\section{Abstract}

Effective integrated weed management requires understanding the impacts of management strategies applied alone and in combination. The objectives of this study were to determine the effects of 2,4-D and repeated sheep (Ovis aries) grazing applied alone and in combination on spotted knapweed (Centaurea maculosa Lam.) and perennial grasses. We hypothesized that integrating a single spring 2,4-D application would remove the adult plants, repeated sheep grazing would control rosettes, and spotted knapweed density, cover and biomass would decrease, allowing residual grasses to reoccupy the sites. A single spring 2,4-D application at $2.1 \mathrm{~kg}$ a.i. ha $^{-1}$, repeated annual sheep grazing of 95\% spotted knapweed or $60 \%$ grass utilization, and repeated sheep grazing and 2,4-D combined were applied to small pastures at 2 sites in western Montana beginning in 1997 and continued through 2001. Spotted knapweed rosette and flowering plant density, and spotted knapweed and perennial grass cover and biomass were sampled from 1998 through 2001 . Spotted knapweed rósette density was $61.7,34.3,44.3$, and $0.3 \mathrm{~m}^{-2}$ in the control, sheep grazing, 2,4-D, and combined sheep grazing and 2,4-D treatments, respectively, at 1 site in 2001. Spotted knapweed flowering plant density increased from 3.7 in 1998 to $10.7 \mathrm{~m}^{-2}$ in 2002 in the 2,4-D treatment whereas there was no increase in the 2,4-D combined with sheep grazing treatment from 1998 to 2002. Perennial grass biomass was $6.9,8.4,25.7$, and 19.7 in the control, sheep grazing, 2,4-D, and combined sheep grazing and 2,4-D treatments, respectively, averaged for both sites and 4 years of sampling. Herbicides released perennial grasses from weed competition and changed the weed population from mature, less palatable plants to juvenile plants that were preferred by sheep.

Key Words: Centaurea maculosa, noxious rangelands weeds, integrated weed management, grazing weeds

The pervasiveness and persistence of invasive plants, combined with their cost of control supports the argument for implementing integrated management (Sheley and Petroff 1999). Walker and Buchanan (1982) defined integrated weed management as "the application of many kinds of technologies in a mutually supportive manner." Integrated weed management involves the deliberate selection, integration, and implementation of effective inva-

Research was funded in part by the Montana Department of Agriculture, Noxious Weed Trust Fund. Authors wish to thank Dan Lucas for his help in conducting the research, and Steve Sherick and Vikki Weaver for providing sheep for the study.

Manuscript accepted 20 Oct. 03

\section{Resumen}

Un manejo integrado de maleza efectivo requiere del entendimiento de los impactos de las estrategias de manejo aplicadas solas o en combinación. Los objetivos de este estudio fueron determinar los efectos de 2,4-D y el apacentamiento repetido de ovinos ( $O$ vis aries), aplicados solos y en combinación, sobre el "Spotted knapweed" (Centaurea maculosa Lam.) y los zacates perennes Hipotetizamos que integrando una sola aplicación de 2,4-D en primavera removería las plantas adultas y el apacentamiento repetido con ovinos controlaría las rosetas y por lo tanto la densidad, cobertura y biomasa de "Spotted knapweed" decrecerían permitiendo a los zacates perennes remanentes ocupar nuevamente los sitios. En potreros pequeños de dos sitios del oeste de Montana se aplicaron los siguientes tratamientos: una sola aplicación en primavera de $2,4-\mathrm{D}$ a razón de $2.1 \mathrm{~kg}$ i.a. $\mathrm{ha}^{-1}$, apacentamiento anual repetido por ovinos del $95 \%$ del "Spotted knapweed" o el $60 \%$ de utilización de los zacates y el apacentamiento repetido mas aplicación de 2,4-D, el estudio inicio en 1997 y continuo hasta el 2001 . La densidad de rosetas y plantas floreando de "Spotted knapweed" y la biomasa y cobertura de "Spotted knapweed"y zacates perennes se muestrearon de 1998 al 2001. En el sitio 1, en el 2001 la densidad de rosetas de "Spotted knapweed" fue de $61.7,34.3,44.3$ y $0.3 \mathrm{~m}^{-2}$ en los tratamientos control, apacentamiento de ovinos, 2,4-D y la combinación de ambos respectivamente En el tratamiento de 2,4-D la densidad de plantas floreando de "Spotted knapweed" se incrementó de 3.7 en 1998 a $10.7 \mathrm{~m}^{-2}$ en el 2002 mientras que en el tratamiento de la combinación de 2,4-D con apacentamiento con ovinos no se registro incremento alguno. La biomasa de zacates perennes, promedio de los dos sitios y los cuatro años de muestreo, fue de $6.9,8.4$, 25.7 y 19.7 en el tratamiento control, apacentamiento con ovinos, 2,4-D y la combinación de 2,4-D con apacentamiento con ovinos respectivamente. Los herbicidas liberaron a los zacates perennes de la competencia ejercida por la maleza y cambiaron la población de maleza de una madura y menos gustosa a plantas juveniles que fueron preferidas por los ovinos.

sive plant management strategies with due consideration of economic, ecological, and sociological consequences. To be deliberate about integration and to achieve management goals, understanding the impacts of management strategies applied alone and in combination on the weed and the plant community is important. An overall goal of integrated weed management is to maintain or develop ecologically healthy plant communities that are relatively resistant to invasion, while meeting other land-use objectives such as forage production, wildlife habitat, or recreation (Sheley et al. 1996). Grazing animals and their management 
can be a major component of integrated invasive plant management to rehabilitate rangeland (Fay 1991, Olson 1999).

Plant community response to grazing depends upon the intensity, frequency, and timing of grazing, the relative preferences of animals, and the relative ability of plants to resist or tolerate grazing (Maschinski and Whitman 1989). Much research has focused on matching particular weeds with animals that prefer eating them. For example, leafy spurge (Euphorbia esula L.) can be managed using sheep (Ovis aries) and goats (Capra hircus) (Landgraf et al. 1994, Olson and Wallander 2001). A general strategy has been to graze leafy spurge to about $60 \%$ utilization, 2 or 3 times each year, during the spring and summer, and if flowering reinitiates, in the fall. Less is known about grazing most other weeds, such as oxeye daisy (Chrysanthemum leucanthemum L.) (Olson et al. 1997a) and spotted knapweed (Centaurea maculosa Lam.) (Olson et al. 1997b). However, grazing alone may not be the most effective management for invasive species (Sheley and Petroff 1999).

Integrating grazing with other weed management techniques has considerable promise (Olson 1999). Lym et al. (1997) found that using sheep or goat grazing to remove excess plant material provided better leafy spurge control than using picloram. Applying management to alter the palatability of invasive weeds and the preference of animals for them, along with altering the weed population's resistance to grazing, may improve weed control using grazing animals. For example, Olson et al. (1997b) found that areas repeatedly grazed by sheep had lower densities of seedlings, rosettes, and mature spotted knapweed plants than ungrazed areas, and that the proportion of young plants in the population was less in grazed areas than ungrazed areas. This suggested that sheep preferred young tender growth over more mature plant parts. In addition, density of the perennial grass, Idaho fescue (Festuca idahoensis Elmer), increased. The fescue leaves and flower culms were $38 \%$ and $17 \%$ shorter, respectively, in the grazed areas than in non-grazed areas (Olson et al. 1997b). Therefore, a low residual herbicide, such as 2,4-D, may be used to kill adult plants and create a population of seedlings that are preferred by sheep. The seedling stage is probably the least resistant to grazing (Olson et al. 1997b). Herbicide application may also release desirable perennial grasses suppressed by competition with spotted knapweed.

The objective of this study was to deter- mine the effects of integrating 2,4-D and repeated sheep grazing on spotted knapweed-infested plant communities. We hypothesized that integrating a single spring 2,4-D application would remove the adult plants, repeated sheep grazing would control rosettes, and spotted knapweed density, cover and biomass would decrease, allowing residual grasses to reoccupy the sites. We predict that integrating these 2 management tools will have a greater effect on spotted knapweed than either applied alone, and provide sustainable management of spotted knapweed.

\section{Materials and Methods}

\section{Study Sites}

Field studies were conducted from 1997 to 2001 on 2 sites in western Montana, USA, to evaluate the effect of a single spring application of $2,4-D$, repeated annual sheep grazing, and combining a single spring application of 2,4-D with repeated sheep grazing on spotted knapweed-infested rangeland. Both sites were abandoned hayfields dominated by spotted knapweed. Introduced grasses were also present, but suppressed by spotted knapweed competition and cattle (Bos taurus) grazing. Site 1 was located along the Bitterroot River near Missoula, Mont. $\left(46.83^{\circ} \mathrm{N}, 114.05^{\circ} \mathrm{W}\right)$. It had spotted knapweed density of approximately 32 plants $\mathrm{m}^{-2}$ at the start of the study, and grass species present were Kentucky bluegrass (Poa pratensis L.), intermediate wheatgrass (Thinopyron intermedium L.), and cheatgrass (Bromus tectorum L.). The soil was a flood plain xerofluvent with less than 5\% slope (Carter 1998). Average (30 year) annual precipitation is $350 \mathrm{~mm}$ and there is a 120-day frost free period. Site 2 was on the Clark Fork River flood plain near Drummond, Mont. (46.79० $\mathrm{N}$, $\left.113.20^{\circ} \mathrm{W}\right)$. Spotted knapweed density was approximately 97 plants $\mathrm{m}^{-2}$ at the start of the study. Kentucky bluegrass and intermediate wheatgrass were present. Drummond soil was a very well-drained Winspect series loamy-skeletal, mixed, superactive, frigid Typic Calciustolls with a slope of less than 5\% (Carter 1998). Average annual precipitation is $450 \mathrm{~mm}$ and the frost free period is 90 days. Both sites were fenced to prevent grazing by cattle during the study.

\section{Experimental Design}

Four treatments were applied in a randomized complete block design and repli- cated 3 times at each site. Treatment plots at Missoula and Drummond were $9 \times 23$ and $15 \times 31 \mathrm{~m}$, respectively. The treatments were: 1) a control which received no 2,4-D or repeated grazing; 2) repeated sheep grazing of $95 \%$ knapweed utilization or $60 \%$ grass utilization repeated thrice in 1998, 1999, and twice in 2000 and 2001 ; 3) 2,4-D amine applied in spring 1997 at the rate of $2.1 \mathrm{~kg}$ a.i. ha ${ }^{-1}$, and 4) 2,4-D amine applied in spring 1997 at the rate of $2.1 \mathrm{~kg}$ a.i. ha ${ }^{-1}$ combined with repeated sheep grazing of $95 \%$ knapweed utilization or $60 \%$ grass utilization repeated thrice in 1998, 1999, and twice in 2000 and 2001. Utilization percentages were visually estimated. Missoula and Drummond were treated with 2,4-D on 14 July 1997 and 11 July 1997, respectively, using a truck mounted tank sprayer delivering 450 liters $\mathrm{ha}^{-1}$. The sheep grazing treatments were timed by the phenology of spotted knapweed. The first grazing began when spotted knapweed was in the rosette to early bolting stage, usually in late May. Subsequent grazing was determined by the spotted knapweed regrowth and targeted bolted stems and buds to prevent seed production, usually in late June and July. Drought conditions in 2000 and 2001 prevented regrowth of spotted knapweed after the second grazing and a third grazing was not applied. Missoula was grazed by 4 rams and duration of grazing for each plot ranged from 1 to 4 days depending on the amount of knapweed present. Drummond was grazed by 20 ewes and 1 ram and with a similar duration as Missoula.

\section{Sampling}

Density and biomass of spotted knapweed and biomass of grass were sampled in September 1998 through 2001. Spotted knapweed and grass cover were sampled in September 1999, 2000, and 2001. Four sub-samples were randomly taken from each plot. Spotted knapweed rosette and flowering plant density was measured by counting the number of plants of each growth stage within a 0.2 by $0.5 \mathrm{~m}$ frame (Daubenmire 1970) placed on the ground randomly within each plot. Spotted knapweed and grass percent cover were visually estimated from the same sample plot as spotted knapweed density. Biomass of spotted knapweed and grass were sampled by clipping plants to the ground within a $0.44 \mathrm{~m}^{2}$ circular hoop placed over the area where density and cover were sampled. Plants were separated by species when clipped, dried to a constant weight in an oven $\left(60^{\circ} \mathrm{C}, 48\right.$ hours), and weighed. 


\section{Analysis}

Treatment effects on density, cover, and biomass were analyzed using analysis of variance (SAS Inc. 1990). Sites were analyzed separately. The model included replication, treatment, year, and the treatment by year interaction. Data were square root transformed to meet assumptions of normality and homogeneity of variance. When a significant $(P \leq 0.05)$ F-test was calculated, differences among means were tested using Fishers protected least significant differences (LSD) procedures (Peterson 1985).

\section{Results}

\section{Spotted knapweed}

Rosette density. Spotted knapweed rosette density at Missoula was affected by treatment (Table 1). Rosette density was lower in the 2,4-D treatment and sheep grazing combined with $2,4-\mathrm{D}$ treatment compared to the control and sheep grazing treatment (Table 2). At Drummond, treatment and year interacted to affect spotted knapweed rosettes (Table 1). In 1998 and 1999 there were no treatment effect on rosettes (Table 3). In 2000, sheep grazing combined with 2,4-D reduced rosette density compared to the control and where 2,4-D was applied. Sheep grazing reduced rosettes compared to the control. By 2001, sheep grazing combined with 2,4-D reduced rosettes compared to all other treatments.

Flowering plant density. Treatment and year interacted to affect flowering plant density at Missoula and Drummond (Table 1). At Missoula in 1998, flowering plant density was lower in the 2,4-D treatment compared to the control but not the sheep grazing treatment (Table 3 ). Combining sheep grazing and 2,4-D reduced flowering plants compared to the control and the sheep grazing treatment. In 1999, the 2,4D treatment and the sheep grazing combined with 2,4-D treatment reduced flowering plant density compared to the control and the sheep grazing treatment. In 2000 , all treatments reduced flowering plant density compared to the control, and combining sheep grazing with 2,4-D reduced flowering plant density compared to the 2,4-D and sheep grazing treatments. By 2001, flowering plant density in the 2,4-D treatment was no different than that of the control. Sheep grazing and sheep grazing combined with $2,4-\mathrm{D}$ reduced flowering plant density compared to the control but was not different than the 2,4D treatment.

Table 1. P-values generated from ANOVA of spotted knapweed rosette density, flowering plant density, and biomass, and grass biomass at Missoula and Drummond, Mont. testing the effect of 2, 4-D and sheep grazing treatments over the years 1998 through 2001.

\begin{tabular}{|c|c|c|c|c|c|}
\hline \multirow[t]{2}{*}{ Source of variation } & \multirow[b]{2}{*}{ df } & \multicolumn{2}{|c|}{ Spotted Knapweed } & \multicolumn{2}{|c|}{ Grass } \\
\hline & & $\begin{array}{l}\text { rosette } \\
\text { density }\end{array}$ & $\begin{array}{c}\text { flowering } \\
\text { plant density }\end{array}$ & biomass & biomass \\
\hline \multicolumn{6}{|l|}{ Missoula } \\
\hline Rep & 2 & 0.1740 & 0.0626 & 0.7645 & 0.2472 \\
\hline Treatment & 3 & 0.0001 & 0.0001 & 0.0001 & 0.0001 \\
\hline Year & 3 & 0.1159 & 0.0001 & 0.0104 & 0.1271 \\
\hline Treatment*year & 9 & 0.0727 & 0.0075 & 0.0012 & 0.5979 \\
\hline \multicolumn{6}{|l|}{ Drummond } \\
\hline Rep & 2 & 0.5432 & 0.8606 & 0.0315 & 0.3580 \\
\hline Treatment & 3 & 0.0001 & 0.0001 & 0.0457 & 0.0002 \\
\hline Year & 3 & 0.0003 & 0.0001 & 0.3672 & 0.0007 \\
\hline Treatment*year & 9 & 0.0332 & 0.0071 & 0.4217 & 0.1636 \\
\hline
\end{tabular}

Table 2. The effect of 2,4-D and sheep grazing treatments on spotted knapweed rosette density, spotted knapweed cover, grass cover and grass biomass at Missoula, Mont, and spotted knapweed and grass biomass at Drummond, Mont. Means are for non-transformed data and are combined over the 4 years of sampling. Letters following means indicate significant differences between means determined by $\operatorname{LSD}(\alpha=0.05)$ calculated from transformed data.

\begin{tabular}{|c|c|c|c|c|c|c|}
\hline \multirow[b]{3}{*}{ Treatment } & \multicolumn{4}{|c|}{ Missoula } & \multicolumn{2}{|c|}{ Drummond } \\
\hline & \multicolumn{2}{|c|}{ Spotted knapweed } & \multicolumn{2}{|c|}{ Grass } & \multirow{2}{*}{$\begin{array}{l}\text { Spotted } \\
\text { knapweed } \\
\text { Biomass }\end{array}$} & \multirow{2}{*}{$\begin{array}{c}\text { Grass } \\
\text { Biomass }\end{array}$} \\
\hline & Rosettes & Cover & Cover & Biomass & & \\
\hline None & $14.1 \mathrm{a}$ & $39 a$ & $7 \mathrm{~b}$ & $6.6 \mathrm{~b}$ & $62.7 \mathrm{a}$ & $7.2 \mathrm{~b}$ \\
\hline Sheep & $19.1 \mathrm{a}$ & $11 \mathrm{~b}$ & $11 \mathrm{~b}$ & $6.1 \mathrm{~b}$ & $32.3 \mathrm{a}$ & $10.6 \mathrm{~b}$ \\
\hline $2,4-\mathrm{D}$ & $2.6 \mathrm{~b}$ & $10 \mathrm{~b}$ & $25 \mathrm{a}$ & $24.3 \mathrm{a}$ & $59.2 \mathrm{a}$ & $27.1 \mathrm{a}$ \\
\hline Sheep + 2,4-D & $2.6 \mathrm{~b}$ & $5 \mathrm{c}$ & $27 \mathrm{a}$ & $17.7 \mathrm{a}$ & $27.1 \mathrm{~b}$ & $21.6 \mathrm{a}$ \\
\hline
\end{tabular}

Table 3. The effect of 2,4-D and sheep grazing treatments and year on spotted knapweed flowering plant density and biomass at Missoula, Mont., and spotted knapweed rosette and flowering plant density at Drummond, Mont. Means are for non-transformed data. Letters following means indicate significant differences between means determined by LSD $(\alpha=0.05)$ calculated from square root transformed data.

\begin{tabular}{|c|c|c|c|c|c|c|c|c|c|}
\hline \multirow{3}{*}{$\begin{array}{l}\text { Year } \\
1998\end{array}$} & \multirow{3}{*}{$\begin{array}{l}\text { Treatment } \\
\text { None }\end{array}$} & \multicolumn{4}{|c|}{ Missoula } & \multicolumn{4}{|c|}{ Drummond } \\
\hline & & \multicolumn{2}{|c|}{$\begin{array}{l}\text { Flowering plan } \\
\left.-\mathrm{m}^{-2}\right)\end{array}$} & \multicolumn{2}{|c|}{$\begin{array}{l}\text { Biomass } \\
-\left(\mathrm{g} \mathrm{m}^{-2}\right)-\end{array}$} & \multicolumn{2}{|c|}{ Rosettes } & \multicolumn{2}{|c|}{$\begin{array}{l}\text { Flowering plants } \\
\mathrm{m}^{-2} \text { )- }\end{array}$} \\
\hline & & 5.8 & de & 114.3 & a & 11.2 & defg & 1.4 & g \\
\hline 1998 & Sheep & 4.9 & def & 35.3 & efg & 2.3 & fg & 1.1 & g \\
\hline 1998 & $2,4-D$ & 0.7 & fg & 18.0 & ghi & 4.7 & efg & 3.7 & efg \\
\hline 1998 & Sheep+2,4-D & 0.2 & $\mathrm{~g}$ & 3.3 & $\mathrm{j}$ & 6.3 & efg & 2.3 & $\mathrm{~g}$ \\
\hline 1999 & None & 21.3 & $a b$ & 71.7 & bc & 16.1 & bcde & 13.3 & bcd \\
\hline 1999 & Sheep & 15.5 & $\mathrm{bc}$ & 19.0 & fghi & 12.4 & cdef & 7.2 & def \\
\hline 1999 & $2,4-D$ & 0.7 & $\mathrm{~g}$ & 8.7 & hij & 7.5 & defg & 4.9 & defg \\
\hline 1999 & Sheep+2,4-D & 1.7 & ef & 8.7 & hij & 3.9 & efg & 1.7 & g \\
\hline 2000 & None & 29.7 & a & 72.3 & b & 215.5 & abcd & 35.3 & a \\
\hline 2000 & Sheep & 8.0 & $\mathrm{~cd}$ & 10.3 & hi & 3.5 & efg & 24.3 & $a b$ \\
\hline 2000 & $2,4-D$ & 12.7 & cd & 52.3 & bcde & 21.0 & bcde & 7.8 & def \\
\hline 2000 & Sheep+2,4-D & 2.2 & ef & 3.7 & j & 0.3 & g & 4.9 & $\mathrm{fg}$ \\
\hline 2001 & None & 7.3 & cd & 42.7 & cdef & 61.7 & a & 18.7 & bc \\
\hline 2001 & Sheep & 0.5 & g & 6.0 & $\mathrm{i}$ & 34.3 & $a b c$ & 8.0 & def \\
\hline 2001 & 2,4-D & 3.0 & defg & 21.0 & fgh & 44.3 & $a b$ & 10.7 & cde \\
\hline 2001 & Sheep+2,4-D & 0.6 & g & 5.0 & $\mathrm{j}$ & 0.3 & $\mathbf{g}$ & 2.0 & fg \\
\hline
\end{tabular}

At Drummond in 1998, flowering plant density was not different in any of the treatments (Table 3). In 1999, combining sheep grazing with 2,4-D reduced flowering plant density compared to the control and the sheep grazing treatment, but not the 2,4-D treatment. In 2000, 2,4-D and combining sheep grazing with $2,4-D$ reduced flowering plants compared to the control and the sheep grazing treatment. By 2001, flowering plant density in the 2,4-D treatment was no different than the control, sheep grazing reduced flowering plants compared to the control, but not the 
Table 4. P-values generated from ANOVA of spotted knapweed and grass cover at Missoula and Drummond, Mont. testing the effect of 2, 4-D and sheep grazing treatments over the years 1999 through 2001.

\begin{tabular}{lccc}
\hline \hline Source & \multicolumn{2}{c}{ Spotted knapweed } & Grass \\
\cline { 2 - 3 } Missoula & df & cover & cover \\
Rep & 2 & 0.1477 & 0.1047 \\
Treatment & 3 & 0.0001 & 0.0001 \\
Year & 2 & 0.9897 & 0.6475 \\
Treatment*year & 6 & 0.0596 & 0.3460 \\
Drummond & & & \\
Rep & 2 & 0.0759 & 0.1827 \\
Treatment & 3 & 0.0001 & 0.0001 \\
Year & 2 & 0.0001 & 0.0073 \\
Treatment*year & 6 & 0.0432 & 0.0005 \\
\hline
\end{tabular}

2,4-D treatment, and combining sheep grazing with $2,4-D$ reduced flowering plants compared to the 2,4-D treatment and the control.

Cover. Spotted knapweed cover was affected by treatment at Missoula (Table 4.) All treatments reduced cover compared to the control (Table 2). Combining sheep grazing with 2,4-D reduced cover compared to the sheep grazing and 2,4-D treatments.

Treatment interacted with year to affect spotted knapweed cover at Drummond (Table 4). In 1999, only sheep grazing combined with 2,4-D reduced cover compared to the control (Table 5). In 2000 and 2001, cover was not different in the 2,4-D treatment compared to the control. Sheep grazing and sheep grazing combined with 2,4-D reduced cover compared to the control, but not compared to the 2,4-D treatment.

Biomass. Treatment and year interacted to affect spotted knapweed biomass at Missoula (Table 1). All treatments reduced biomass compared to the control in 1998 , and sheep grazing combined with 2,4-D reduced biomass compared to the sheep grazing and 2,4-D treatments (Table 3 ). In 1999, all treatments reduced biomass compared to the control, but there were no differences between treatments. In 2000, biomass was the same in the 2,4D treatment as the control, sheep grazing reduced biomass compared to the control and 2,4-D, and sheep grazing combined with 2,4-D reduced biomass compared to all other treatments. By 2001, biomass was the same in the 2,4-D treatment as the control, biomass was the same in the sheep grazing treatment as sheep grazing combined with 2,4-D, and the sheep grazing treatment and sheep grazing combined with 2,4-D treatment were lower than the 2,4-D treatment and control.

Spotted knapweed biomass was affected by treatment at Drummond (Table 1). Sheep grazing combined with 2,4-D reduced biomass compared to the 2,4-D treatment and the control (Table 2). There were no other treatment differences.

\section{Perennial grass}

Perennial grass cover. Treatment affected cover at Missoula (Table 4). Cover was similar in the control and the sheep grazing treatment, cover was similar in the 2,4$\mathrm{D}$ and the sheep grazing combined with 2,4-D treatments, and cover was greater in the 2,4-D and the sheep grazing combined with 2,4-D treatments compared to the control and the sheep grazing treatments (Table 2).

At Drummond, treatment and year interacted to affect perennial grass cover (Table 4). In 1999, cover was greater in the 2,4-D treatment compared to the control, and cover was greater in the sheep grazing combined with 2,4-D treatment compared to all other treatments (Table 5). In 2000, perennial grass cover was greater where sheep grazing was combined with 2,4-D than the control and the sheep grazing treatment, and cover was greater in the 2,4-D treatment than all other treatments. By 2001 , the sheep grazing and 2,4-D treatment had more cover than the control, and combining sheep grazing with $2,4-\mathrm{D}$ resulted in more cover than all other treatments.

Biomass. Treatment affected perennial grass biomass at Missoula and Drummond (Table 1). At both sites, the 2,4-D treatment and sheep grazing combined with 2,4-D had more biomass than the sheep grazing treatment and the control (Table 2).

Year affected biomass at Drummond (Table 1). Grass biomass was greater in $2001\left(29 \mathrm{~g} \mathrm{~m}^{-2}\right)$ compared with $2000(17 \mathrm{~g}$ $\left.\mathrm{m}^{-1}\right), 1999\left(10 \mathrm{~g} \mathrm{~m}^{-1}\right)$, and $1998\left(13 \mathrm{~g} \mathrm{~m}^{-1}\right)$.

Table 5. The effect of 2,4-D and sheep grazing treatments and year on spotted knapweed and perennial grass cover (\%) at Drummond, Mont. Means are for non-transformed data. Letters following means indicate significant differences between means determined by LSD $(\alpha=0.05)$ calculated from square root transformed data.

\begin{tabular}{llrlrl}
\hline \hline Year & Treatment & Spotted knapweed & Grass \\
\hline & & & & \\
\hline & & & & & \\
1999 & None & 20 & bcd & 10 & fg \\
1999 & Sheep & 16 & bcde & 16 & ef \\
1999 & $2,4-D$ & 13 & cde & 22 & de \\
1999 & Sheep+2,4-D & 5 & e & 34 & abc \\
2000 & None & 37 & ab & 10 & fg \\
2000 & Sheep & 11 & & 8 & g \\
2000 & 2,4-D & 30 & bcd & 40 & ab \\
2000 & Sheep+2,4-D & 11 & de & 25 & cde \\
2001 & None & 61 & a & 7 & g \\
2001 & Sheep & 23 & bcd & 28 & cd \\
2001 & 2,4-D & 31 & abc & 34 & bc \\
2001 & Sheep+2,4-D & 13 & cde & 46 & a \\
\hline
\end{tabular}

\section{Discussion and Conclusions}

Herbicide studies in the late 1970 s showed 2,4-D provided at least $80 \%$ spotted knapweed control for a single year when applied early in the growing season (Belles et al. 1980, Wattenbarger et al. 1980). Most studies of the influence of 2,4-D on spotted knapweed were shortterm. Studies conducted beyond a single growing season indicate substantial site to site variation. For example, Wattenbarger et al. (1980) applied 2,4-D amine at a rate of 1.1 and $2.1 \mathrm{~kg}$ a.i. ha ${ }^{-1}$ in Bonner County, Ida., and Lemhi County, Ida., in the spring of 1978 . By 1979 , these rates of 2,4-D reduced spotted knapweed by 75 and $91 \%$, respectively in Bonner County, but only 30 and $60 \%$, respectively in Lemhi County. In Montana, 2,4-D applied at 1.1 and $2.2 \mathrm{~kg}$ a.i. $\mathrm{ha}^{-1}$ reduced spotted knapweed density by $50 \%$ at one site and $75 \%$ at a second site 2 seasons after application (Jacobs and Sheley 1999). A single application of 2,4-D at a rate of $2.1 \mathrm{~kg}$ a.i. $\mathrm{ha}^{-1}$ on 2 flood plain sites in our study reduced spotted knapweed production by $40 \%$ four years after application. The treatments that included 2,4-D resulted in the highest perennial grass cover and biomass throughout our 4-year study. Grass competition is important in delaying the re-establishment of spotted knapweed (Sheley et al. 1998). The trend over time of increasing spotted knapweed rosette density, cover, and biomass suggests that the sites will return to spotted knapweed dominance when herbicide management is used alone without repeated applications (Belles et al. 1980, Davis 1990).

Our results suggest that the value of herbicides in sustainable weed management is the short-term control of weeds, and the long-term increase in perennial grass production and competition with spotted knapweed. Our sites had a residual population of competitive non-native perennial grasses. Sites dominated by annual grasses may require revegetation with perennial grasses to improve productivity. A diverse forb component was absent at our sites but we believe a carefully timed applica tion of a non-residual herbicide, like 2,4 $\mathrm{D}$, may provide land managers a method for controlling spotted knapweed while preserving forb diversity (Jacobs and Sheley 1999). Forb diversity may be criti. cal to ecosystem functioning and invasion resistence of native plant communities (Pokorny 2002).

Spotted knapweed is highly nutritious (Kelsey and Mihalovich 1987, Olson and Wallander 2001) and sheep tend to prefer 
broad-leaved forbs over either grasses or shrubs (Hanley 1982). Our findings indicate that sheep provide good control of spotted knapweed, and in some cases, the level of control was better than that of 2,4$D$ alone. The trend over time indicates that grasses responded favorably to the grazing system of $95 \%$ spotted knapweed or $60 \%$ grass utilization applied in this study. This conclusion supports the results of Olson and Wallander (2001) suggesting wellmanaged sheep grazing may help restore a balance in competitive relations between spotted knapweed and perennial grasses.

We found strong evidence supporting our hypothesis that integrating a spring 2,4-D application to remove the adult plants combined with repeated sheep grazing to control seedling and juvenile plants would decrease spotted knapweed density, cover, and biomass, allowing residual grasses to reoccupy the sites. Combining 2,4-D and sheep grazing caused the greatest decrease in spotted knapweed rosette density 5 years after treatment began. At the Drummond site, there was a dramatic increase in rosette density over time when 2,4-D was used alone, and a dramatic decrease in rosette density where 2,4-D and repeated sheep grazing were combined. These results support those of Olson et al. (1997b) that areas repeatedly grazed by sheep had lower densities of seedlings, rosettes, and mature spotted knapweed plants than ungrazed areas, and that the proportion of young plants in the population was less in grazed areas than ungrazed areas. We believe the herbicide changed the knapweed population to plants more palatable to sheep by controlling the adult plants, and sheep preferred seedlings and regrowth from crowns over that of associated grasses.

\section{Literature Cited}

Belles, W. S., D. W. Wallenbarger, and G. A. Lee. 1980. Spotted knapweed control in noncropland. Western Soc. Weed Sci. Res. Prog. Rep. ISSN 009-8142:55-56.

Carter, J. 1998. Integrating herbicide, fertilizer, and grazing to manage spotted knapweed infested rangeland. M. S. thesis. Montana State Univ., Bozeman, Montana. 47p.

Daubenmire, R. 1970. Steppe vegetation of Washington. Washington Agr. Exp. Sta. Tech. Bull. No. 62 .

Davis, E. S. 1990. Spotted knapweed (Centaurea maculosa Lam.) seed longevity, chemical control and seed morphology. M.S. Thesis. Montana State Univ. Bozeman, Mont. 109 pp.

Fay, P. K. 1991. Controlling leafy spurge with grazing animals. In: L.F. James, J.O. Evans, M.H. Ralphs, and R.D. Child (eds.) Noxious Range Weeds. Westview Press, Bolder Colo, 193-199.

Hanley, T.A. 1982. The nutritional basis for food selection by ungulates. J. Range Manage. 35:146-151.

Jacobs, J.S. and R.L. Sheley. 1999. Response of spotted knapweed, other forbs, and grass to 2,4-D and N-fertilizer combinations. J. Range Manage. 52:482-488.

Kelsey, R. G. and R. D. Mihalovich. 1987. Nutrient composition of spotted knapweed (Centaurea maculosa). J. Range Manage. 40(3):277-281.

Landgraf, B.L., P.K. Fay, and K.M. Havstad. 1994. Utilization of leafy spurge (Euphorbia esula) by sheep. Weed Sci. 42:348.

Lym, R.G., K.K. Sedivec, and D.R. Kirby. 1997. Leafy spurge control with angora goats and herbicides. J. Range Manage. 50:123-128.

Maschinski. J. and T.G. Whitman. 1989. The continuum of plant responses to herbivory: the influence of plant association, nutrient availability, and timing. Amer. Natur. 134:1-9.
Olson, B.E. 1999. Grazing weeds. In: R. L. Sheley and J. K. Petroff (eds.) Biology and Management of Noxious Rangeland Weeds. Oregon State Univ. Press. p. 85-96.

Olson, B.E. and R.T. Wallander. 2001. Sheep grazing spotted knapweed and Idaho fescue. J. Range Manage. 54:25-30.

Olson, B.E., R.T. Wallander, and P.K. Fay. 1997a. Intensive cattle grazing of oxeye daisy. Weed Technol. 11:176-81

Olson, B.E., R.T. Wallander, and J.R. Lacey. 1997b. Effects of sheep grazing on a spotted knapweed-infested Idaho fescue community. J. Range Manage. 50:386-390.

Peterson, R.G. 1985. Design and analysis of experiments. Marecel Dekker, Inc. New York, N.Y.

Pokorny, M.L. 2002. Plant functional group diversity as a mechanism for invasion resistance. M.S. Thesis, Montana State Univ., Bozeman, Mont. 130 p.

SAS Inc. 1990. SAS/STAT User's Guide, Ver 6. Vol. 2. Cary, NC: Statistical Analysis Systems Institute. $920 \mathrm{p}$.

Sheley, R.L. and J. K. Petroff. 1999. Biology and Management of Noxious Rangeland Weeds. Oregon State Univ. Press. 438 p.

Sheley, R.L., J.S. Jacobs, and M.F. Carpinelli. 1998. Distribution, biology, and management of diffuse (Centaurea diffusa) and spotted knapweed (Centaurea maculosa). Weed Technol. 12:353-362.

Sheley, R. L., T. J. Svejcar, and B. D. Maxwell. 1996. A theoretical framework for developing successional weed management strategies on rangeland. Weed Technol. 7:766-773.

Walker, R.H. and G.A. Buchanan. 1982. Crop manipulations in integrated weed management systems. Weed Sci. 30:17-24.

Wattenbarger, D.W., W.S. Belles, and G.A. Lee. 1980. Effect of herbicides on the control of spotted knapweed in rangelands. Western Soc. of Weed Sci. Res. Progr. Rept. Salt Lake City, Utah. p. 63-64. 